\title{
Assessment of Water Quality of Some Private Borehole in Port Harcourt, Rivers State Case Study, Diobu Community.
}

\author{
Odunze Wisdom C.N., Nwachukwu Chinonso
}

\begin{abstract}
This study investigated the assessment of water quality of some private borehole in Port Harcourt metropolis case study Diobu Community. Four research questions and four hypotheses guided the study.

The related literature review was done under the theoretical/conceptual, empirical studies and summary which identified the assessment of water quality of some private borehole in Port Harcourt metropolis. Descriptive survey research design was adopted for the study.

A 40- item structured questionnaire development by the research was used. Questionnaire was used for data collection, Descriptive statistic of mean and standard deviation were used to answer the research question while chi-square was used to test the hypotheses at 005 level of significance. The finding indicated that there is no significant mean difference in the causes of water contamination of private borehole in port Harcourt metropolises. The study revealed that the ground water pollution causes contamination of water in private borehole. Some private borehole owner in Diobu community do not test the quality of their boreholes. It is re-commended that standard measures should be taken by the appropriate authorities to ensure proper treatment of the water to safeguard the health of the innocent consumers.
\end{abstract}

Index Terms - Borehole, Water Quality, Contamination, Port Harcourt.

\section{INTRODUCTION}

Groundwater which is also the source of private borehole water supply is one of the most important resources available to humanity; therefore it is more than necessary to provide a tool that can assess its quality over space and time. Groundwater exists below the surface of the ground in the spaces between particles of rock or soil, or in the crevices and cracks in rocks, usually within 100 meters of the surface of the Earth. Groundwater plays a substantial role in water supply, in ecosystem functioning and human well-being. Worldwide, 2.5 billion people depend solely on groundwater resources to satisfy their basic daily water needs, and hundreds of millions of farmers rely on groundwater to sustain their livelihoods and contribute to the food security of so many others.

Odunze, Wisdom C.N.,Ph.D Department of Environmental Science IMO State Polytechnic, Umungwo, Nigeria

Corresponding Author: drmrswisdomodunze@gmail.com

Nwachukwu, Chinonso, Department of Environmental Science, National Open University of Nigeria, Port Harcourt Study Centre, Nigeria
Groundwater supplies are diminishing, with an estimated 200/o of the world's aquifers being over-exploited, leading to serious consequences such as land subsidence and saltwater intrusion in coastal areas. The major sources of pollution in streams, rivers and underground water arise from anthropogenic activities largely caused by the poor and uncultured living habit of people as well as the unhealthy practices of factories, industries and corporate bodies; resulting in the discharge of untreated effluents and waste. Rivers state is a wetland in the Niger delta with likely serious problems of drinking water. Groundwater studies in some areas in Rivers State have shown increased levels in Total Dissolved Solids (TDS) ( up to $2900 \mathrm{mg} / \mathrm{L}$ ), high hydrocarbon content oil and grease $(71 \mathrm{mg} / \mathrm{L}$ in 2006 compared to 1.8 $\mathrm{mg} / \mathrm{L}$ recorded seventeen years earlier) are reported to be some of the groundwater problems according to Ayotamuno and Kogbara (2010 and 2011) had reported iron and chloride elevation as groundwater issues and this was corroborated by Ophori et al (2012). Similar problems as reflected in Bayelsa, Delta and Rivers States were also reported by Arnangabara and Ejenma (2013), Edet(2014), and Amadi ci al.(2015).The principal goal of groundwater monitoring and management in developing countries is to assess and manage the water resources that are available. Groundwater is an important source of drinking water for more than half of Nigeria's population and nearly all its rural population; it is generally a very good source of drinking water because of the self-purifying properties of the soil, therefore there is the need for regular monitoring and assessment of these drinking water sources. This is because monitoring provides data on groundwater quantity and quality and it is an integral aspect of groundwater management (2016)-(2017). However, the quality assessment of private boreholes in some selected community in Port Harcourt Metropolis has not been reported, hence, this study is aimed at assessing the groundwater quality samples from Diobu Community to provide baseline data which will be used as a guide for future monitoring and to determine the extent of contamination by comparing results with local and international standardized limits.

Groundwater sources are being increasingly used as drinking water yet, testing to see whether the water is of good quality is almost non-existent. Although, it is true that soils generally function to reduce the effect of microorganisms by a simple filtration mechanism, especially larger bacterial and protozoa, pollution of groundwater by micro-organisms, especially the located near septic tanks or landfills 
significantly do occur

\section{STATEMENT OF THE PROBLEM}

Groundwater sources are being increasingly used as drinking water yet, testing to see whether the water is of good quality is almost non-existent. Although, it is true that soils generally function to reduce the effect of microorganisms by a simple filtration mechanism, especially larger bacterial and protozoa, pollution of groundwater by microorganisms, especially the located near septic tanks or landfills significantly do occur

\section{Objective of the Study}

The aim of this study is to assess the water quality of some private borehole in Port Harcourt metropolis using questionnaire method this was achieve to:

1. Access the water quality in Port Harcourt metropolis.

2. Examine the causes of contamination of private borehole water.

3. To examine the effect of private borehole contamination

4. To determine the possible contamination control measure of private borehole water in Diobu Community

\section{Research Questions}

1) What is water quality in Port Harcourt metropolis?

2) What are the causes of contamination of private borehole water?

3) What is the effect of private borehole contamination?

4) What are the possible contamination control measures of private borehole water in Diobu Community?

\section{Hypotheses}

The follow hypotheses were formulated and tested at 001 level of significance.

$\mathrm{Ho}_{1}$, there is no significant mean difference in the water quality rating among respondent based on the demographic variables.

$\mathrm{Ho}_{2}$ : there is no significant mean difference in the casus of water contamination of private borehole based on demographic variables.

$\mathrm{Ho}_{3}$ : there is no significant mean difference in the effect of private borehole contamination based on demographic variable.

$\mathrm{Ho}_{4}$ : there is no significant mean different in the control contamination private borehole water based on demographic variable.

\section{Methods:}

The study adopted a descriptive research survey design to enhance generalization of findings, the study is confined to Diobu which consists of three main extension namely; mile1, mile2, and mile3, it is boarded by new GRA to the North, D-line to the north east, Rivers state University to the northeast old GRA to the east, kidney island to the south east, eagle island to the South West, the coordinates of Diobu are $4^{0} 47$ '24N $6^{0} 59^{\prime} 3^{\prime} 6^{\prime \prime} \mathrm{E}$. ( Latitude 4.772152: Longitude $6.9945147)$.

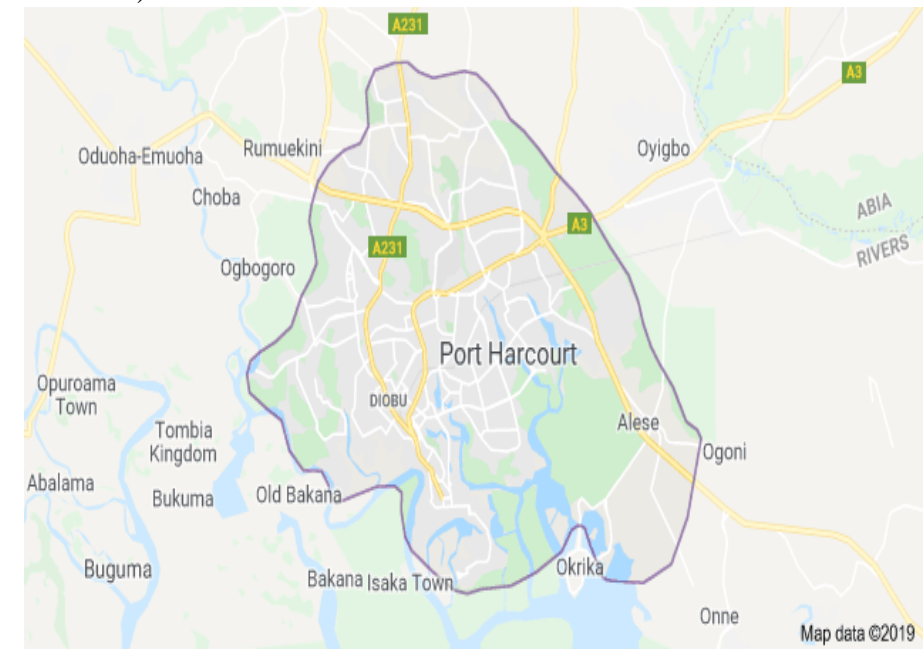

Figure 1.1 Port Harcourt Map showing Diobu Area in Rivers State

A sample of 200 questionnaires was used for the study.

40 item structured questionnaire developed by the research was used "WATER QUALITY" causes of contamination of private borehole, effect of private borehole contamination and control of contamination of private borehole water in Diobu community in Port Harcourt metropolis. The data collected was analyzed using simple descriptive statistics of means and standard deviation to answer research question.

A mean cut off point of 3.37 was used for decision making the hypotheses were tested using chi-square test by TAMANI formula to arrive at the sample population of the study.

\section{RESULT AND FINDING}

This section present and discuss the result of the study

Research question 1: What is water quality in Port Harcourt metropolis?

Table 1: Summary of mean rating of the water quality in Diobu Port Harcourt metropolis

\begin{tabular}{|c|c|c|c|c|c|c|c|}
\hline $\mathbf{S} / \mathbf{N}$ & WATER QUALITY & SA & $\mathbf{A}$ & D & SD & Mean & STD \\
\hline 1 & Most of the private borehole in Diobu have taste & 86 & 62 & 28 & 19 & 3.10 & 0.98 \\
\hline 3 & $\begin{array}{l}\text { The boreholes water in } \\
\text { Diobu community contains black particles? }\end{array}$ & 21 & 149 & 16 & 9 & 2.93 & 0.61 \\
\hline
\end{tabular}




\begin{tabular}{|c|l|c|c|c|c|c|c|}
\hline & $\begin{array}{l}\text { often by government and non-government } \\
\text { standard organization }\end{array}$ & & & & & & \\
\hline 5 & $\begin{array}{l}\text { Most of the Private borehole in Diobu Community } \\
\text { uses granular magnesium dioxide (Salt) for water } \\
\text { treatment }\end{array}$ & 72 & 61 & 57 & 5 & 3.03 & 0.88 \\
\hline 6 & $\begin{array}{l}\text { Setting and filtration is a physical process used in } \\
\text { treating water quality }\end{array}$ & 70 & 58 & 48 & 19 & 2.92 & 1.00 \\
\hline 7 & $\begin{array}{l}\text { Private boreholes are used in Port Harcourt } \\
\text { Metropolis, } \\
\text { mostly in Diobu Community }\end{array}$ & 92 & 84 & 9 & 10 & 3.32 & 0.79 \\
\hline 8 & $\begin{array}{l}\text { Colour in water is primarily a concern of water } \\
\text { quality for } \\
\text { aesthetic reason }\end{array}$ & 143 & 45 & 3 & 4 & 3.68 & 0.61 \\
\hline $\begin{array}{l}\text { Water purification is a measure taken to ensure water } \\
\text { quality treatments }\end{array}$ & 102 & 61 & 19 & 13 & 3.29 & 0.90 \\
\hline 10 & $\begin{array}{l}\text { Taste and odour are human perceptions of water } \\
\text { quality, Human perceptions of taste includes Sour } \\
\text { (hydrochloric acid), salty sodium chloride), sweet } \\
\text { (sucrose) and bitter (caffeine) }\end{array}$ & 117 & 48 & 13 & 17 & 3.36 & 0.94 \\
\hline
\end{tabular}

Overall Mean Scores 3.180 .45

SA - Means strongly Agreed
A - Means Agreed
D - Means disagreed
SD - Means strongly disagreed
STD - Means Standard Deviation

The result from Table 1 shows the summary of mean rating of water quality in Diobu Port Harcourt metropolis. It shows that the grand mean rating of water quality in Diobu Port Harcourt metropolis was $3.18, \mathrm{STD}=0.45$. Specifically, the result also shows that the mean rating of colour in water is primarily a concern of water quality for aesthetic reason. Coloured water give the appearance of being unfit to drink was 3.68, STD=0.61 whereas Taste and odours are human perceptions of water quality. Human perception of taste includes sour (hydrochloric acid), salty (sodium chloride), sweet (sucrose) and bitter(caffeine)? Was 3.36, STD=0.94. and that of The sites in Diobu Community are checked often

Table 2: Summary of mean rating of Causes of contamination of private borehole water in Diobu Port Harcourt Metropolis.

\begin{tabular}{|c|c|c|c|c|c|c|c|}
\hline $\mathbf{S} /$ & $\begin{array}{l}\text { Causes of } \\
\text { contamination of private borehole water }\end{array}$ & $\mathbf{S A}$ & $\mathbf{A}$ & D & D $^{\text {ST }}$ & Mean & $\begin{array}{l}\text { STD } \\
\end{array}$ \\
\hline 1 & $\begin{array}{l}\text { When hazardous waste is disposed or dumped in } \\
\text { a site, it leads to contamination ground water } \\
\text { after some time }\end{array}$ & 135 & 50 & 6 & 4 & 3.62 & 0.65 \\
\hline 2 & $\begin{array}{l}\text { Any borehole located close to a landfill site } \\
\text { will produce contaminated water }\end{array}$ & 111 & 84 & 0 & 0 & 3.57 & 0.50 \\
\hline 3 & $\begin{array}{l}\text { Atmospheric pollutant is one of the agent of } \\
\text { water pollution }\end{array}$ & 118 & 77 & 0 & 0 & 3.61 & 0.49 \\
\hline 4 & $\begin{array}{l}\text { Oil spillage in an area can directly or } \\
\text { indirectly contaminate the ground water }\end{array}$ & 161 & 29 & 5 & 0 & 3.80 & 0.46 \\
\hline
\end{tabular}

by government and non government standard organization was $3.34, \mathrm{STD}=0.73$, while Setting and filtration is a physical process used in treating water quality is a measure of the light-transmitting properties of water and is comprised of suspended and colloidal material was rated with mean score of 3.29, STD $=0.90$, and Most of the Private borehole in Diobu Community uses Granular Magnesium dioxide (salt) for water treatment had mean rating of 3.17. STD $=0.90$.

Research Question: 2 What are the Causes of Contamination of Private Borehole Water. 


\begin{tabular}{|c|c|c|c|c|c|c|c|}
\hline 5 & $\begin{array}{l}\text { Chemicals like road salts, solvents used in the } \\
\text { area are part are source ground water } \\
\text { contamination }\end{array}$ & 140 & 49 & 6 & 0 & 3.69 & 0.53 \\
\hline 6 & $\begin{array}{l}\text { Pesticide is prone to washing into the soil } \\
\text { after heavy rainfalls which will also lead to } \\
\text { contamination ground water }\end{array}$ & 111 & 77 & 7 & 0 & 3.53 & 0.57 \\
\hline 7 & $\begin{array}{l}\text { Animal waste in the area will cause } \\
\text { contamination of water }\end{array}$ & 89 & 75 & 31 & 0 & 3.30 & 0.73 \\
\hline 8 & $\begin{array}{l}\text { Arsenic is a chemical in rock, ground water } \\
\text { flows from the rock when these } \\
\text { chemical contaminate the ground water, it } \\
\text { capable of poisoning both human and animals }\end{array}$ & 95 & 75 & 25 & 0 & 3.36 & 0.70 \\
\hline 9 & $\begin{array}{l}\text { Radon gas is a natural pollutant that can cause } \\
\text { serious problem to human or animals that } \\
\text { consumes water contaminated with it }\end{array}$ & 73 & 105 & 15 & 2 & 3.28 & 0.65 \\
\hline 10 & $\begin{array}{l}\text { Contamination of ground water is the major } \\
\text { source contaminated boreholes }\end{array}$ & 94 & 99 & 2 & 0 & 3.47 & 0.52 \\
\hline
\end{tabular}

Grand Mean 3.520 .33

\section{The Result from Table 2}

Shows the summary of mean rating Control of Contamination of Private Borehole Water in Diobu Community, It shows that the grand mean rating of water quality in Diobu Port Harcourt metropolis was 3.52, $\mathrm{STD}=0.33$. Specifically, the result also shows that the mean rating of Oil spillage in an area can directly or indirectly. Contaminate the ground water.3.80, $\mathrm{STD}=0.46$ where as that of Chemicals like road salts, solvents used in the area are part of the area are part of the source of ground water

Table 3: Summary of Mean Scores Rating of the Effect of Private Borehole Contamination Dibou Community in Port Harcourt Metropolis.

\begin{tabular}{|c|c|c|c|c|c|c|c|}
\hline $\mathbf{N}^{\mathbf{S} /}$ & $\begin{array}{l}\text { Effect of } \\
\text { contamination of private borehole water }\end{array}$ & $\mathbf{S A}$ & $\mathbf{A}$ & D & $\mathrm{D}^{\mathrm{ST}}$ & Mean & STD \\
\hline 1 & $\begin{array}{l}\text { Most of the disease that affects children in Diobu } \\
\text { Community is traceable to contaminated water } \\
\text { which they drink }\end{array}$ & 119 & 76 & 0 & 0 & 3.61 & 0.49 \\
\hline 2 & $\begin{array}{l}\text { Groundwater infected with hepatitis is the major } \\
\text { cause of Hepatitis in human }\end{array}$ & 150 & 45 & 0 & 0 & 3.77 & 0.42 \\
\hline 3 & $\begin{array}{l}\text { Most children in our rural area are suffering } \\
\text { from dysentery because of the intake of } \\
\text { contaminated water }\end{array}$ & 108 & 86 & 1 & 0 & 3.55 & 0.51 \\
\hline 4 & $\begin{array}{l}\text { Any borehole that is not properly dug, or that is } \\
\text { exposed to chemical flow can become } \\
\text { poisonous to human consumption }\end{array}$ & 133 & 62 & 0 & 0 & 3.68 & 0.47 \\
\hline 5 & $\begin{array}{l}\text { When an area has a contaminated groundwater the } \\
\text { land value will be depreciated }\end{array}$ & 95 & 76 & 24 & 0 & 3.36 & 0.69 \\
\hline 6 & $\begin{array}{l}\text { Contamination of groundwater reduces the } \\
\text { nutrient of the land }\end{array}$ & 73 & 60 & 62 & 0 & 3.06 & 0.83 \\
\hline 7 & $\begin{array}{l}\text { An area with contaminated ground water } \\
\text { cannot be used as an industrial area }\end{array}$ & 74 & 59 & 62 & 0 & 3.06 & 0.83 \\
\hline 8 & $\begin{array}{l}\text { Vegetations are affected when the groundwater is } \\
\text { contaminated }\end{array}$ & 25 & 148 & 18 & 4 & 2.99 & 0.55 \\
\hline 9 & $\begin{array}{l}\text { The degree of Private borehole contamination is } \\
\text { high in Diobu Community }\end{array}$ & 83 & 106 & 6 & 0 & 3.39 & 0.55 \\
\hline 10 & $\begin{array}{l}\text { Some private borehole water owner in Diobu } \\
\text { community does not take care or wash their } \\
\text { storage up to } 10 \text { years }\end{array}$ & 102 & 92 & 1 & 0 & 3.52 & 0.51 \\
\hline
\end{tabular}

contamination. $3.69, \mathrm{STD}=0.53$ it also shows that when hazardous waste is dispose or dumped in a site, it leads to contamination of groundwater after some time 3.62, $\mathrm{STD}=0.65$, and also the mean rating of Atmospheric pollutant is one of the agent of water pollution $3.61, \mathrm{STD}=0.49$ and also the least Any borehole located close to a landfill site will produce a contaminated water was $3.57, \mathrm{STD}=0.50$

Research Question 3: What is the Effect of Private Borehole Contamination? 


\begin{tabular}{|c|l|c|c|c|c|c|c|}
\hline 11 & $\begin{array}{l}\text { Private borehole owner in Diobu community test } \\
\text { their water always }\end{array}$ & 72 & 61 & 62 & 0 & 3.05 & 0.83 \\
\hline
\end{tabular}

Grand Mean 3.370 .37

The result from Table 3 shows the summary of mean rating of Effect of Private Borehole Contamination in Diobu Community, It shows that the grand mean rating of Effect of Private Borehole Contamination in Diobu Port Harcourt metropolis was 3.37, STD=0.37 Specifically, the result also shows that the mean rating of ground water infected with hepatitis is the major cause of Hepatitis in human. 3.77, $\mathrm{STD}=0.42$ where as any borehole that is not properly dug, or that is exposed to chemical flow can become poisonous to human consumption. $3.68, \mathrm{STD}=0.47$, it also shows that Most of the disease that affects children in Diobu Community is

traceable to contaminated. $3.61, \mathrm{STD}=0.49$, and also the mean rating Most children in our rural area are suffering from dysentery because of the intake of contaminated water. 3.55 , $\mathrm{STD}=0.51$ and also the some private borehole water owner in Diobu Community does not take care or wash their storage tank for up to 10 years $3.52 \mathrm{STD}=0.51$

Research Question 4: What are the possible Contamination control measures of Private Borehole Water in Diobu Community

Table 4: Summary Of Mean Scores Rating of Control Contamination of Private Borehole Water in Diobu Community in Port Harcourt Metropolis

\begin{tabular}{|c|c|c|c|c|c|c|c|}
\hline $\mathbf{N}^{\mathbf{S} /}$ & $\begin{array}{l}\text { Control of } \\
\text { contamination of private borehole water }\end{array}$ & SA & $\mathbf{A}$ & $\mathbf{D}$ & $\mathrm{D}^{\text {ST }}$ & Mean & STD \\
\hline 1 & $\begin{array}{l}\text { Government should always send their law enforcement } \\
\text { agents, to make sure people abide with the law and } \\
\text { regulation guiding quality of water }\end{array}$ & 98 & 93 & 4 & 0 & 3.48 & 0.54 \\
\hline 2 & $\begin{array}{l}\text { Private borehole owner should ensure the cleanness } \\
\text { of their storage tank always }\end{array}$ & 139 & 55 & 1 & 0 & 3.71 & 0.47 \\
\hline 3 & $\begin{array}{l}\text { Dump sites should not be located close to resident area } \\
\text { where it will affect water flowing to the borehole }\end{array}$ & 120 & 75 & 0 & 0 & 3.62 & 0.49 \\
\hline 4 & $\begin{array}{l}\text { Due examination of water should be done periodically } \\
\text { by the private borehole owners to detect when the } \\
\text { water becomes contaminated }\end{array}$ & 140 & 55 & 0 & 0 & 3.72 & 0.45 \\
\hline 5 & $\begin{array}{l}\text { Joint effort should put in place for cleaning of } \\
\text { contamination in the environment }\end{array}$ & 115 & 67 & 9 & 4 & 3.50 & 0.68 \\
\hline 6 & $\begin{array}{l}\text { Series of test should be done on groundwater of an area } \\
\text { before that site can be chosen as borehole site }\end{array}$ & 107 & 88 & 0 & 0 & 3.55 & 0.50 \\
\hline 7 & $\begin{array}{l}\text { Discharge of petroleum product in any community of } \\
\text { Diobu or its environs should be reported to the appropriate } \\
\text { quarters to avoid contamination of ground water }\end{array}$ & 117 & 78 & 0 & 0 & 3.60 & 0.49 \\
\hline 8 & $\begin{array}{l}\text { Rearing of some animal like pig, cow etc should not be } \\
\text { located near drinking borehole to avoid contamination } \\
\text { of water through animal waste }\end{array}$ & 61 & 111 & 21 & 2 & 3.18 & 0.66 \\
\hline 9 & $\begin{array}{l}\text { Hazardous chemicals should not be disposed } \\
\text { inappropriately }\end{array}$ & 81 & 80 & 34 & 0 & 3.24 & 0.73 \\
\hline 10 & $\begin{array}{l}\text { Old boreholes which was a conversion from dug well } \\
\text { to borehole should be closed down because of health } \\
\text { implication of contaminated water }\end{array}$ & 88 & 76 & 31 & 0 & 3.29 & 0.73 \\
\hline
\end{tabular}

Grand Mean 3.490 .34

The result from Table 4 shows the summary of mean rating of Control of Contamination of Private Borehole Water in Diobu Community, It shows that, the grand mean rating of Control of Contamination of Private Borehole Water in Diobu Community, was 3.49, STD=0.34 Specifically, the result also shows' that the mean rating Due examination of water should be done periodically by the private borehole owner to detect when the water become contaminated. 3.72, $\mathrm{STD}=0.45$ where as Private borehole owner should ensure the cleanness of their storage tank always.3.71, STD $=0.47$, it also shows that Dump sites should not be located close to resident area where it will affect water flowing to the borehole 3.62,
$\mathrm{STD}=0.49$, and also the mean rating of Discharge of petroleum product in any community of Diobu or its environ should be reported to the appropriate quarters to avoid contamination of ground water $.3 .60, \mathrm{STD}=0.49$ and also the least and not the last was Series of test should be done on groundwater of an area before that site can be chosen as borehole site. $3.55 \mathrm{STD}=0.50$

\section{HYPOTHESIS TESTING}

$\mathrm{H}_{1}$ : There is no significant mean difference in the water quality rating among respondent based on the demographic variables.

Table 1: Summary of the factorial Analysis of Variance on the mean difference in the water quality rating among respondent based on the demographic variables 


\begin{tabular}{|l|l|l|l|l|l|}
\hline Source & $\begin{array}{l}\text { Type III } \\
\text { Sum of } \\
\text { square }\end{array}$ & Df & $\begin{array}{l}\text { Mean } \\
\text { Square }\end{array}$ & F & Sig \\
\hline Corrected & $6.004 \mathrm{a}$ & 11 & .546 & 3.019 & .001 \\
\hline Model Intercept & 299.823 & 1 & 299.823 & 1658.731 & .000 \\
\hline GENDER & .010 & 1 & .010 & .055 & .814 \\
\hline AGE & .208 & 4 & .052 & .288 & .886 \\
\hline MARITAL STATUS & 5.155 & 3 & 1.718 & 9.507 & .000 \\
\hline EDU QUALIFICATION & .047 & 3 & .016 & .087 & .967 \\
\hline Error & 33.078 & 183 & .181 & & \\
\hline
\end{tabular}

Total 2016.149195

Corrected Total $39.082 \quad 194$

a. $\mathrm{R}$ Squared $=.154$ (Adjusted R Squared .103)

The result from Table 1 shows the summary of the factorial Analysis of Variance on the mean difference in the water quality rating among respondent based on the demographic variables. It shows that only marital status(F1, 1839.507, $\mathrm{p}<.05)$ as significant over mean difference in the water quality rating among respondent, whereas $\mathrm{Age}(\mathrm{F} 4,183=.288$,

p>. 05), gender(F1, 183=.055) and Educational qualification (F3, 188=.087, p >.05) were not significant over mean difference in the water quality rating among respondent.

$\mathrm{HO}_{2}$ : There is no significant mean difference in the cause of water contamination of private borehole based on demographic variables.

Table 2: Summary of the factorial Analysis of Variance on the mean difference in the cause of water contamination of private borehole rating among respondent based on the demographic variables

\begin{tabular}{|l|l|l|l|l|l|}
\hline Source & $\begin{array}{l}\text { Type III } \\
\text { Sum of square }\end{array}$ & Df & Mean Square & F & Sig \\
\hline Corrected & $.712 \mathrm{a}$ & 11 & .065 & .578 & .846 \\
\hline Model Intercept & 380.960 & 1 & 380.960 & 3397.004 & .000 \\
\hline GENDER & .140 & 1 & .140 & 1.245 & .266 \\
\hline AGE & .370 & 4 & .093 & .826 & .510 \\
\hline MARITAL STATUS & .124 & 3 & .041 & .368 & .776 \\
\hline QUALIFICATION & .043 & 3 & .014 & .128 & .943 \\
\hline Error & 20.523 & 183 & .112 & & \\
\hline
\end{tabular}

Total 2440.180195

Corrected Total 21.235194 -

a. R Squared .034 (Adjusted R Squared $=-.025$ )

The result from Table 2 shows the summary of the factorial Analysis of Variance on the mean difference in the cause of water contamination of private borehole respondent based on the demographic variables. It shows that there were no significant mean difference in the cause of water contamination of private borehole based on marital status

$(\mathrm{F} 3, \quad 183=.368, \quad \mathrm{p}>.0 \mathrm{~S}), \quad \operatorname{Age}(\mathrm{F} 4, \quad 183=.826, \quad \mathrm{p}>. \quad 05)$, gender(F1, 1831.245, $\mathrm{p}>05)$ and Educational qualification $(\mathrm{F} 3,188.128, \mathrm{p}>.05)$ respectively

$\mathrm{HO}_{3}$ : There is no significant mean difference in the effect of private borehole contamination based on demographic variables.

Table 3: Summary of the factorial Analysis of Variance on the mean difference in the Effect Of Private Borehole rating among respondent based

on the demographic variables

\begin{tabular}{|l|l|l|l|l|l|}
\hline Source & $\begin{array}{l}\text { Type III Sum of } \\
\text { square }\end{array}$ & Df & Mean Square & F & Sig \\
\hline Corrected Model & $2.007 \mathrm{a}$ & 11 & .182 & 1.359 & .196 \\
\hline Intercept & 365.125 & 1 & 365.125 & 2719.434 & .000 \\
\hline GENDER & .093 & 1 & .093 & .691 & .407 \\
\hline AGE & 1.059 & 4 & .265 & 1.972 & .101 \\
\hline MARITAL STATUS & .348 & 3 & .116 & .864 & .461 \\
\hline QUALIFICATION & .446 & 3 & .149 & 1.108 & .347 \\
\hline Error & 24.570 & 183 & .134 & & \\
\hline
\end{tabular}

Total 2239.152195

Corrected Total 26.578194

a. R Squared $=.076$ (Adjusted R Squared $=.020$ )

The result from Table 3 shows the summary of the factorial Analysis of Variance on the mean difference in the effect of private borehole respondent based on the demographic variables. It shows that there were no significant mean

difference in the effect of private borehole respondent based on marital status(F3, 183=864, p>.05), age (F4, 183=.1.972, p>. 05), gender(F1, 183=691, p>05) and Educational qualification $(\mathrm{F} 3,183=1.108, \mathrm{p}>.05)$ respectively. 
H04: There is no significant mean difference in the control of variable. contamination private borehole water based on demographic

Table 4: Summary of the factorial Analysis of Variance on the mean difference in the Control of Contamination rating among respondent based on the demographic variables

\begin{tabular}{|l|l|l|l|l|l|}
\hline Source & $\begin{array}{l}\text { Type III Sum of } \\
\text { square }\end{array}$ & Df & Mean Square & F & Sig \\
\hline Corrected & $1.080 \mathrm{a}$ & 11 & .098 & .847 & .594 \\
\hline Model Intercept & 386.078 & 1 & 386.078 & 3328.416 & .000 \\
\hline GENDER & .040 & 1 & .040 & .348 & .556 \\
\hline AGE & .673 & 4 & .168 & 1.450 & .219 \\
\hline MARITAL STATUS & .048 & 3 & .016 & .139 & .936 \\
\hline QUALIFICATION & .272 & 3 & .091 & .781 & .506 \\
\hline Error & 21.227 & 183 & .116 & & \\
\hline
\end{tabular}

Total 2396.380195

Corrected Total 22.307194

a. R Squared $=.048$ (Adjusted R Squared $=-.009$ )

The result from Table 4 shows the summary of the factorial Analysis of Variance on the mean difference in the Control of Contamination respondent based on the demographic variables. It shows that there is no significant mean difference in the control of contamination private borehole water based on marital status $(\mathrm{F} 3,183=.139, \mathrm{p}>.05)$ whereas Ae $(\mathrm{F} 4$, $183=.1 .450, \mathrm{p}>$. 05), gender $(\mathrm{Fl}, 183=.348, \mathrm{p}>.05)$ and Educational qualification (F3, 183.781, p>.OS) respectively.

\section{SUMMARY OF FINDINGS}

The key knowledge among water quality in Diobu Port Harcourt metropolis was that Most private borehole water in Diobu Community is full of little particles and greenish substance $(M=3.68, S T D=0.61)$ While the least was that considering the private borehole owner in the Diobu community do water testing in the lab to determine the level of hazardous particles in water. The key knowledge of Causes of contamination of private borehole water in Diobu Port Harcourt Metropolis. is Chemicals like road salts, solvents used in the area are part of the source of ground water contamination. $(\mathrm{M}=3.69, \mathrm{STD}=0.53)$ While the least was Radon gas is a natural pollutant that can cause serious problem to human or animals that consumes water contaminated with it. The key knowledge of Effect of Private Borehole Contamination Dibou Community in Port Harcourt Metropolis Groundwater infected with hepatitis is the major cause of Hepatitis in human. (M=3.77, STD=0.42) and the least was Vegetations are affected when the groundwater is contaminated. The key major knowledge of Control Contamination of Private Borehole Water in Diobu Community in Port Harcourt Metropolis, Due examination of water should be done periodically by the private borehole owners to detect when the water become contaminated is $(\mathrm{M}=3.72, \mathrm{STD}=0.45)$. and the least is Rearing of some animal like pig, cow etc should not be located near drinking borehole to avoid contamination of water through animal waste. Gender has no significant influence on the knowledge of water quality in Diobu Port Harcourt metropolis. Gender has no significant influence on the of Causes of contamination of private borehole water in Diobu Port Harcourt Metropolis. Gender has no significant influence on the Effect of Private Borehole Contamination Dibou Community in Port Harcourt Metropolis.
Gender has no significant influence on Control Contamination of Private Borehole Water in Diobu Community in Port Harcourt Metropolis.

Age has no significant influence on the knowledge of water quality in Diobu Port Harcourt metropolis. Age has no significant influence on the Causes of contamination of private borehole water in Diobu Port Harcourt Metropolis. Age has no significant influence on the Effect of Private Borehole Contamination Dibou Community in Port Harcourt Metropolis.

Age has no significant influence on Control Contamination of Private Borehole Water in Diobu Community in Port Harcourt Metropolis.

Marital Status has no significant influence on the knowledge of water quality in Diobu Port Harcourt metropolis. Marital Status has no significant influence on the of Causes of contamination of private borehole water in Diobu Port Harcourt Metropolis. Marital Status has no significant influence on the Effect of Private Borehole Contamination Dibou Community in Port Harcourt Metropolis.

Marital Status has no significant influence on Control Contamination of Private Borehole Water in Diobu Community in Port Harcourt Metropolis.

Educational Qualification has no significant influence on the knowledge of water quality in Diobu Port Harcourt metropolis. Educational Qualification has no significant influence on the Causes of contamination of private borehole water in Diobu Port Harcourt Metropolis. Educational Qualification has no significant influence on the Effect of Private Borehole Contamination Dibou Community in Port Harcourt Metropolis.

Educational Qualification has no significant influence on Control Contamination of Private Borehole Water in Diobu Community in Port Harcourt Metropolis.

\section{DISCUSSION OF FINDINGS}

Table:1 Water Quality In Diobu Port Harcourt Metropolis

The result from Table 1 shows that water quality in Diobu Port Harcourt metropolis is that colour in water is a primary concern of water quality for aesthetic reason $\quad(M=3.68$, $\mathrm{STD}=0.61$ ) While the least was that considering the private borehole owner in Diobu community do water testing in the 
lab to determine the level of hazardous particles in water. The result from Table 1 shows that gender has no significant influence in water quality in Diobu Port Harcourt metropolis $(\mathrm{F} 1,183=0.55, \mathrm{p}>.05)$. The null hypothesis was retained at 0.05 alpha level. Age has no significant influence in water quality in Diobu Port Harcourt metropolis (F1, 183=0.288, p>.05). The null hypothesis was retained at 0.05 alpha level. Marital Status has no significant influence water quality in Diobu Port Harcourt metropolis $(F 1,183=0.9 .51$, p>.05). The null hypothesis was retained at 0.05 alpha level, Educational Qualification has no significant influence water quality in Diobu Port Harcourt metropolis (F1, 183=087, p>.05). The null hypothesis was retained at 0.05 alpha level.

Table 2: Causes of contamination of private borehole water in Diobu Port Harcourt Metropolis.

The result from Table 2 shows that Causes of contamination of private borehole water in Diobu Port Harcourt Metropolis is Chemicals like road salts, solvents used in the area are part of the source of ground water contamination. $(\mathrm{M}=3.69, \mathrm{STD}=0.53)$ While the least was Radon gas is a natural pollutant that can cause serious problem to human or animals that consumes water contaminated with it. The result from Table 2 shows that gender has no significant influence that Causes of contamination of private borehole water in Diobu (F1, $183=1245, \mathrm{p}>.05)$. Age has no significant influence in the Causes of contamination of private borehole water in Diobu Port Harcourt Metropolis (F4, 183=826, p>.05). The null hypothesis was retained at 0.05 alpha 1 Marital status has no significant influence in the Causes of contamination of private borehole water in Diobu Port Harcourt Metropolis.(F3, 183=.368, p>.05). The null hypothesis was retained at 0.05 alpha level, Educational Qualification has no significant influence in the Causes of contamination of private borehole water in Diobu Port Harcourt Metropolis $(\mathrm{F} 3,183=128, \mathrm{p}>.05)$. The null hypothesis was retained at 0.05 alpha level.

\section{CONCLUSION}

The result showed that some of the parameter used was within normal range for the water samples in the study area were within the acceptable limits by W.H.O and FME standards for drinking water except the $\mathrm{P}^{\mathrm{H}}$ value which was comparatively low in private borehole water samples.

\section{RECOMMENDATION}

It is therefore recommended that standard measures be taken by the appropriate authorities to ensure proper treatment of the waters to safeguard the health of the innocent consumers, total coliforms, and lead in the affected sites.

\section{REFERENCES}

[1] Ademoroti, C. M. (1996). Environmental Issues and Management in Nigerian

[2] Development. I badan. Evans Publisher. pp. 67-75.
[3] Adesiyun, A. A., Adekeye, J. 0., Umoh, J. U. and Nadarajah, M (1983). Studies on Well Water and Possible health Risks in Katsina. Journal of Hygiene. 90:1999-201.

[4] Adesiyun. A. A., Alayande, A. and Adekeye, J. (1999). Studies on Borehole Water and Possible Risks in Kaduna. Nigeria Journal of hygiene. 96:149-160.

[5] Afbede, O. A. and Oladejo, O. S. (2003). Study of Water Quality at Oil Depots in South Western Nigeria. Journal of Environmental Issues. Vol. 1, no. I Pp. 160-165.

[6] Anon (2008). Water Cycle. www.watercycle_answer_gift. AOAC (1985). Association of Official Analytical Chemists. Washington D.C. pp. $15-190$

[7] API IA (1998). American Public Health Association. Standard Methods for the Examination of Water and Waste Water. 20th Edition. Washington L).C pp. 86-98.

[8] Batmanghelid, R. (2009). Water and its Vital Role i the Health of a Water Starved Society. US National Research Council, Food and Nutrition [3ureau. (2) PP. 26-73.

[9] Botkin, D.B and Keller, E.A. (1998). Environmental Science. Earth as a living planet. New York ( $2^{\text {nd }}$ Edition) John Wiley \& Sons Inc. pp. 472-476.

[10] Edungbola, L. D and Asaolu, S. O. (1984). A Parasitological Survey: Onchocerciasis in Babana District of Kwara State, Nigeria. American Journal of Tropical Medicine \& hygiene. 33(999): 1147-1 154.

[11] Eja, M.E. (2002). Water Pollution and Sanitation for Developing Countries. Calabar, Seaprint (Nig) Co. pp. 9-I 0

[12] Ekeh, I. B and Sikoki, F. (2003). The State and Seasonal Variability in Some Physiochemical Parameters of the new Calabar River, Nigeria. Suplementa and Acta hydrobiologica. 5:45-60.

[13] FoeI, E. W. and Nennernan, R. A. (1986). How Peace came to the World. Cambridge. M.I Press. pp. 112-121.

[14] Itah, A. Y. and Akpan, C. E. (2005). Portability of Drinking Water in an Oil Impacted Community in Southern Nigeria. Journal of Applied Science and Environmental Management, 91(1):35-74.

[15] Kulshrcshtha, S. N. (1998). A Global Outlook for Water Resources to the Year 2005. Water Resources Management. 12(3): 167-1 84.

[16] Lehloesa, L. and Muyima, N. Y. (2002). Evaluation of Impact of Household Treatment Procedures in (The Quality of Ground Water Supply in the Rural Community of Victoria District in the Eastern Cape of South Africa. South Africa Water Research 26(2): 285-298.

[17] Miller, G. J. (1992). Environmental Science Sustaining the Earth. California (3rd Edition) Wadsworth Publishing Company. pp. 232-265.

[18] Mishra, A. and Bhatt, V. (2007). Physicochemical and Microbiological Analysis of Underground Water in some Districts in India. E. Journal of Chemistry .5(3): 487- 492.

[19] Muyi, T. D. (2007) Water and the Body. Daily Sun Tuesday, August 7, 2007 edition p. 3

[20] NAFDAC (2004). Training Workshop for Packaged Water and Fruit Juice Products. Ikeja, National Agency for Food and Drugs Administration and Control. pp. 10-1 1

[21] NWRI, (1997). Training Guide for Basic Water Treatment Operations. Kaduna. National Water Resources Institute. p. 1.

[22] Odiette, W. 0 (1999). Environmental Physiology of Animals and Pollution Divers fled Resources. Lagos. pp. 87-218.

[23] Ogan, M. T.(1988). Examination of Surface Water Sources of Domestic Water Supply in Port Harcourt Area. Chemical Hydrology Supply. 79:325-342.

[24] Oni, 0. 0. (1997). Training Guide for Water Quality. Testing and Control, Kaduna. Course Code:1011. National Water Resources Institute. pp. 45-58.

[25] Onwuka, K. 0., Urna, K. 0. and Ezeigbo, H. 1. (2004). Possibility of Shallow Groundwater in Enugu Town, South Eastern Nigeria. Global Journal of Environmental Sciences. 182(3): 33-39.

[26] Sax, N. I. (1994). Industrial Water Pollution. New York. Lition Educational Publications. P. 702.

[27] Strahler, A. I-I. and Sirhler, A. N. (1993). Environmental Sciences: Interaction between National System and Man. New-York: Prentice hall Inc. pp. 96.108.

[28] Tebbut, T. 11. Y. (1983). Principles of Water Quality Control Frankfort (3rd edition). Pergarnon Press. p. 214.

[29] Udoessien, E. 1. (2003). Basic Principles of Environmental Science. Port Harcourt Metropolis. Etiliew International Publishers. pp. 77 110 .

[30] Uriah, N. and Izuagbe, Y. (1990). Water Industries and Public Health Microbiology. Benin City. University of Benin Press. Pp. 18.24,

[31] WHO (1984). Guidelines for Drinking Water Quality. Vol. 1 Geneva. World health Organization Recommendations. pp. 84-101. 
[32] WHO (1985). Guidelines for Drinking Water Quality. Vol. 2 Geneva. World Health Organization Recommendations, Criteria and Other Supporting Information pp. 3-55.

[33] WHO (2006). Guidelines for Drinking Water Quality. Vol. I Geneva. Addendum to the 3rd Value Recommendations. World health Organization. pp. 23-48.

[34] Wolf, A. I. (2001). Water and Human Security. Journal of Contemporary Water Research and Education. 29:118. 